\title{
Microbial Determinations by Flow Cytometry
}

\author{
By K.-J. HUTTER* + AND H. E. EIPEL $\dagger$ \\ * Fraunhofer Gesellschaft, Institut für Aerobiologie, D-5948 Schmallenberg, Germany \\ † Biophysics Systems GmbH, Im Eichenböhl 24, D-6140 Bensheim 3, Germany
}

(Received 16 October 1978; revised 3 January 1979)

\begin{abstract}
Recent improvements in the optics and electronics of flow cytometry systems, as well as in staining techniques, permit the assay of such minute cellular constituents as the DNA and protein contents of micro-organisms. To assess the usefulness of this technique, DNA and protein content distributions were determined in Escherichia coli, Lactobacillus brevis, Lactobacillus casei, Chlorella kessleri 8k, Saccharomyces cerevisiae, Candida utilis, Schizosaccharomyces pombe and Euglena gracilis. Investigations of the DNA content distributions of polyploid strains of Saccharomyces cerevisiae indicated that the method can be used to determine ploidy. The rapidity of flow cytometry measurements allows accurate determinations in large populations.
\end{abstract}

\section{INTRODUCTION}

Pulse cytophotometry was first used for the determination of intracellular substances in micro-organisms in 1974. Using appropriate fluorescence stains and staining techniques, the RNA and protein contents of intact respiratory and respiratory-deficient yeasts of the genus Saccharomyces could be measured during vegetative growth. In these experiments, flow cytometry was used for the first time to determine the ploidy of yeasts. Initially the fluorescent light signals of the yeast DNA were too faint to be recorded by flow cytometry. Thus, the cytometrical measurements of RNA and protein in yeast populations were restricted according to ploidy (Hutter, 1974). Since that time, flow cytometrical evidence of microbial DNA has been extensive (Falchuk et al., 1975; Skogen Hagenson, 1976; Paau et al., 1977a, b; Bailey et al., 1977; Slater et al., 1977; Hutter \& Eipel, 1978a).

The aim of this investigation was to test the usefulness of flow cytometric methods in microbiological assays.

\section{METHODS}

Micro-organisms. These are listed in Table 1.

Preparation of cultures. Organisms were incubated in $100 \mathrm{ml}$ medium in $300 \mathrm{ml}$ Erlenmeyer flasks unless indicated otherwise. Chlorella kessleri $8 \mathrm{k}$ was incubated for $7 \mathrm{~d}$ at $25^{\circ} \mathrm{C}$ and $6 \mathrm{klux}$ in Kessler \& Czygan (1970) medium. Escherichia coli was incubated with shaking for $24 \mathrm{~h}$ at $37^{\circ} \mathrm{C}$ in Merck Standard I nutrient broth. Lactobacilli were grown for $48 \mathrm{~h}$ at $37^{\circ} \mathrm{C}$ in medium containing (per litre) $5 \mathrm{~g}$ sodium acetate, $2 \mathrm{~g}$ diammonium citrate, $0.2 \mathrm{~g} \mathrm{MgSO}_{4} .7 \mathrm{H}_{2} \mathrm{O}$ and $0.05 \mathrm{~g} \mathrm{MnSO}_{4} . \mathrm{H}_{2} \mathrm{O}$ (adjusted to $\mathrm{pH} 6.2$ to 6.5). Yeasts were grown with shaking for $3 \mathrm{~d}$ at $28^{\circ} \mathrm{C}$ in yeast extract peptone medium containing $1 \%(\mathrm{w} / \mathrm{v})$ Difco yeast extract, $2 \%(\mathrm{w} / \mathrm{v})$ Difco Bacto-peptone and $2 \%(\mathrm{w} / \mathrm{v})$ glucose. Nectria coccinea Pers. ex Fr. was incubated at $25^{\circ} \mathrm{C}$ for $5 \mathrm{~d}$ in medium containing (per litre) $30 \mathrm{~g}$ Merck malt extract and $2 \mathrm{~g}$ Difco yeast extract. Due to the filamentous growth of these organisms, the cell suspension was filtered through a polyamide sieve with a mesh size of $65 \mu \mathrm{m}$ (Hutter et al., 1978a); the filtered suspension consisted of spores, microconidia and macroconidia. Euglena gracilis was incubated for $8 \mathrm{~d}$ at $20^{\circ} \mathrm{C}$ in daylight. The medium, prepared in $100 \mathrm{ml}$ Erlenmeyer flasks, consisted of garden soil ( $1 \mathrm{~cm}$ deep), $0.5 \mathrm{~g}$ hard cheese and $50 \mathrm{ml}$ tap water; it was shaken continuously and heated in a boiling water bath for $1 \mathrm{~h}$. After cooling, flasks were inoculated with $5 \mathrm{ml}$ from an old E. gracilis culture (Streble \& Krauter, 1974).

$\ddagger$ Present address: Deutsches Krebsforschungszentrum Heidelberg, Institut für experimentelle Pathologie, Im Neuenheimer Feld 280, D-6900 Heidelberg 1, Germany. 


\section{Table 1. Micro-organisms used}

Organism

Chlorella kessleri $8 \mathrm{k}$

\section{Escherichia coli \\ Saccharomyces pastorianus \\ Schizosaccharomyces pombe \\ Candida utilis \\ Saccharomyces cerevisiae \\ (Baker's yeast) \\ Nectria coccinea Pers. ex Fr. \\ Saccharomyces cerevisiae \\ $(211,300,301,312,400,401,415,500)$ \\ Euglena gracilis}

Lactobacillus casei 20021

Lactobacillus brevis 20054
Source

Prof. Dr Kessler, Botanisches Institut, Universität Erlangen, F.R.G.

Prof. Dr Emeis, Institut für Angewandte Biologie, RWTH Aachen, F.R.G.

Monheimer Presshefe- und Spritwerke GmbH, 4019 Monheim, F.R.G.

Dr Klein, Forstbotanisches Institut, München, F.R.G.

Prof. Dr Pohlit, Institut für Strahlenbiologie,

Frankfurt, F.R.G.

Prof. Mestre, Laboratoire de Biologie Cellulaire,

Université de Paris-Sud, France

) German Collection of Microorganisms,

GSF, München, F.R.G.

Fluorometry of microbial cells. Cells fixed in $70 \%(\mathrm{v} / \mathrm{v})$ ethanol were washed and resuspended in $1 \mathrm{ml}$ $0.2 \mathrm{M}$-Tris buffer; $0.5 \mathrm{ml}$ portions of these suspensions were used for DNA or protein staining.

Protein staining. Cells were treated overnight in fluorescein isothiocyanate (FITC) solution $\left(0.03 \mathrm{mg} \mathrm{ml}^{-1}\right.$

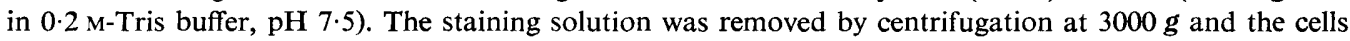
were washed three times in $0.2 \mathrm{M}$-Tris buffer. Immediately before flow cytometry, the cells were resuspended in fresh Tris buffer (Hutter \& Eipel, 1978b).

DNA staining. Cells were treated in $5 \mathrm{ml}$ RNAase solution (Serva; $0 \cdot 1 \%$ in $0 \cdot 2 \mathrm{M}$-Tris buffer, $\mathrm{pH} 7 \cdot 5$ ) for $1 \mathrm{~h}$ at $37^{\circ} \mathrm{C}$ and then for $5 \mathrm{~min}$ at $20^{\circ} \mathrm{C}$ in $2 \mathrm{ml}$ pepsin solution (Serva; $0.5 \%$ in $0.2 \mathrm{M}$-Tris buffer, pH 7.5). They were stained for $15 \mathrm{~min}$ in $5 \mathrm{ml}$ propidium iodide solution (Calbiochem; $0.05 \mathrm{mg} \mathrm{ml}^{-1}$ in $0.2 \mathrm{M}-$ Tris buffer, $\mathrm{pH} 7 \cdot 5$ ). The staining solution was removed by centrifugation and the cells were resuspended in $2 \mathrm{ml} 0 \cdot 2 \mathrm{M}$-Tris buffer.

Apparatus. The flow cytometer used was a Cytofluorograph FC-200-50 (Ortho Instruments, Westwood, Mass., U.S.A.), equipped with a $50 \mathrm{~mW}$ argon laser. The excitation wavelengths were $514.5 \mathrm{~nm}$ for propidium iodide (DNA staining) and $488 \mathrm{~nm}$ for FITC (protein staining). A dichroic mirror with a dividing edge at $570 \mathrm{~nm}$ was inserted into the fluorescence analysis path to separate red and green fluorescence. For propidium iodide measurements, a $590 \mathrm{~nm}$ barrier filter was used in front of the red channel photomultiplier. A special interference filter with a band pass from 515 to $545 \mathrm{~nm}$ was used for FITC. Forward light scatter was measured at angles between $1.5^{\circ}$ and $19^{\circ}$ to the illuminating beam. Two light scatter sensors were mounted on each side of the beam. The light scatter correlated approximately with cell volume.

\section{RESULTS AND DISCUSSION}

Since Strugger's (1949) pioneering work, fluorescence microscopy has become an important tool for microbiological analysis. The information that could be gleaned from measurements with fluorochromed organisms was, however, poor due to the lack of instruments for quantitative determinations. This limitation is overcome by quantitative cytophotometry which avoids time-consuming single cell measurements by using rapid flow-through systems allowing the analysis of more than 1000 cells s $^{-1}$. The time needed to measure the fluorescence of single cell components depends on their specific 'stainability', but is of the order of $5 \mu$ s (Kamentsky et al., 1965; Dittrich \& Göhde, 1969; Kamentsky, 1970; Göhde, 1972).

Flow cytometric measurements can only be correctly interpreted where microbial populations consist of single cells. Micro-organisms which grow in chains, pairs, clusters, tetrads or in filamentous forms or clumps, and those which produce mycelium or pseudomycelium, cannot be measured without pre-treatment. For this reason, Nectria coccinea suspensions were filtered before use (see Methods).

The DNA histograms of Lactobacillus brevis (Fig. 1c), Lactobacillus casei (Fig. 1d), Escherichia coli (Fig. 1f), Chlorella kessleri 8k (Fig. 1g) and Nectria coccinea Pers. ex_Fr. 


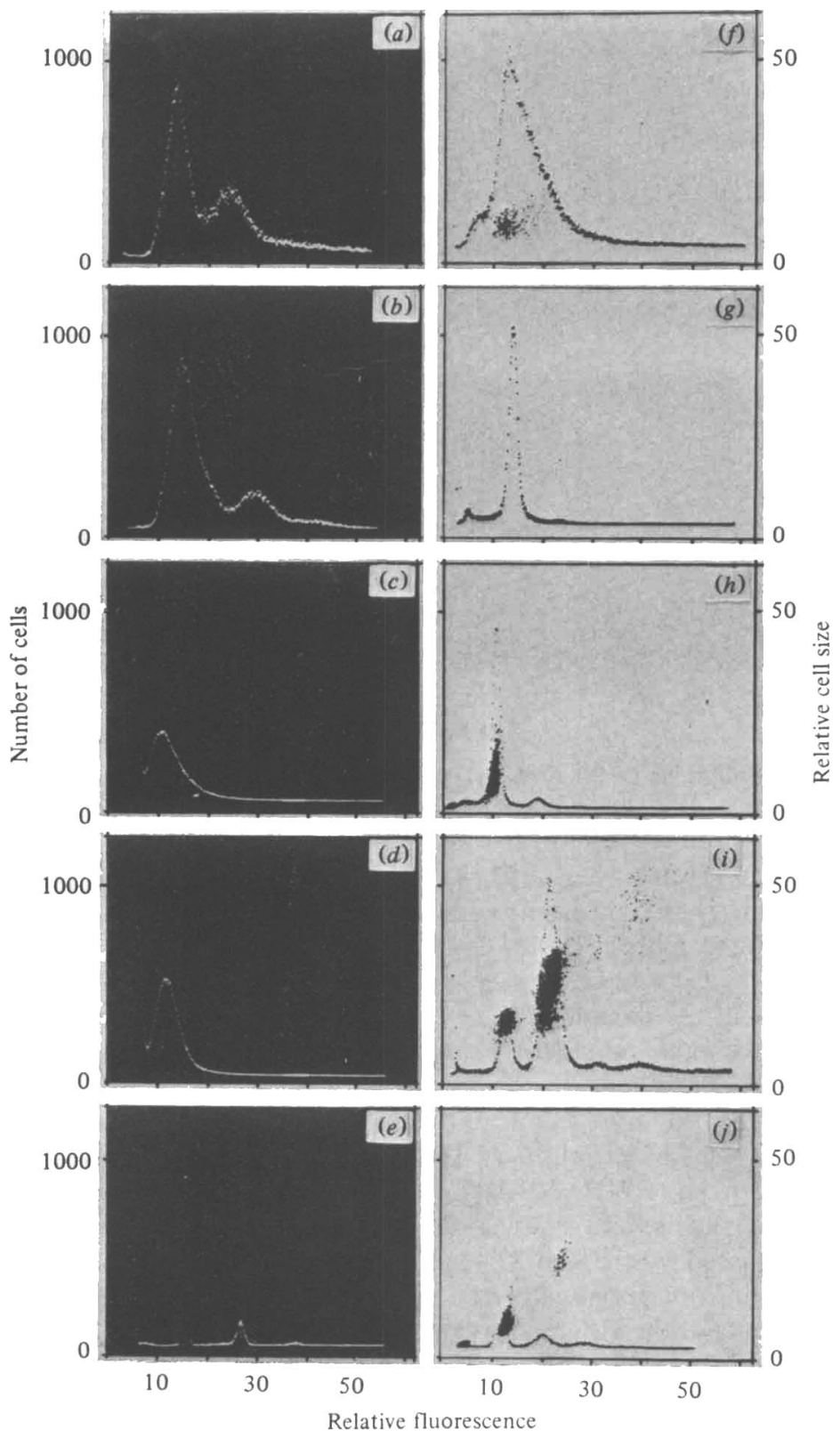

Fig. 1. Flow cytometric measurements of the DNA content of (a) Schizosaccharomyces pombe, (b) Candida utilis, (c) Lactobacillus brevis 20054, (d) Lactobacillus casei 20021, (e) Euglena gracilis, ( $f)$ Escherichia coli, $(g)$ Chlorella kessleri 8k, $(h)$ Nectria coccinea Pers. ex Fr., $(i)$ Saccharomyces cerevisiae and $(j)$ baker's yeast.

(Fig. $1 \mathrm{~h}$ ) each showed a single peak whereas the histograms of Schizosaccharomyces pombe (Fig. 1 a), Candida utilis (Fig. 1b), Euglena gracilis (Fig. $1 e$ ), Saccharomyces cerevisiae (Fig. $1 i$ ) and baker's yeast (Fig. $1 j$ ) consisted of two or more peaks, representing two-, three- or fourfold higher DNA contents. Alternatively, aggregated cells may have been responsible for the extra peaks or, in the case of yeasts, the initiation of a new round of bud formation may have been measured. Figure 1(i) shows a semi-continuous culture of proliferating yeast cells, most of which are in the G2 phase. The end of this period is marked by cell 


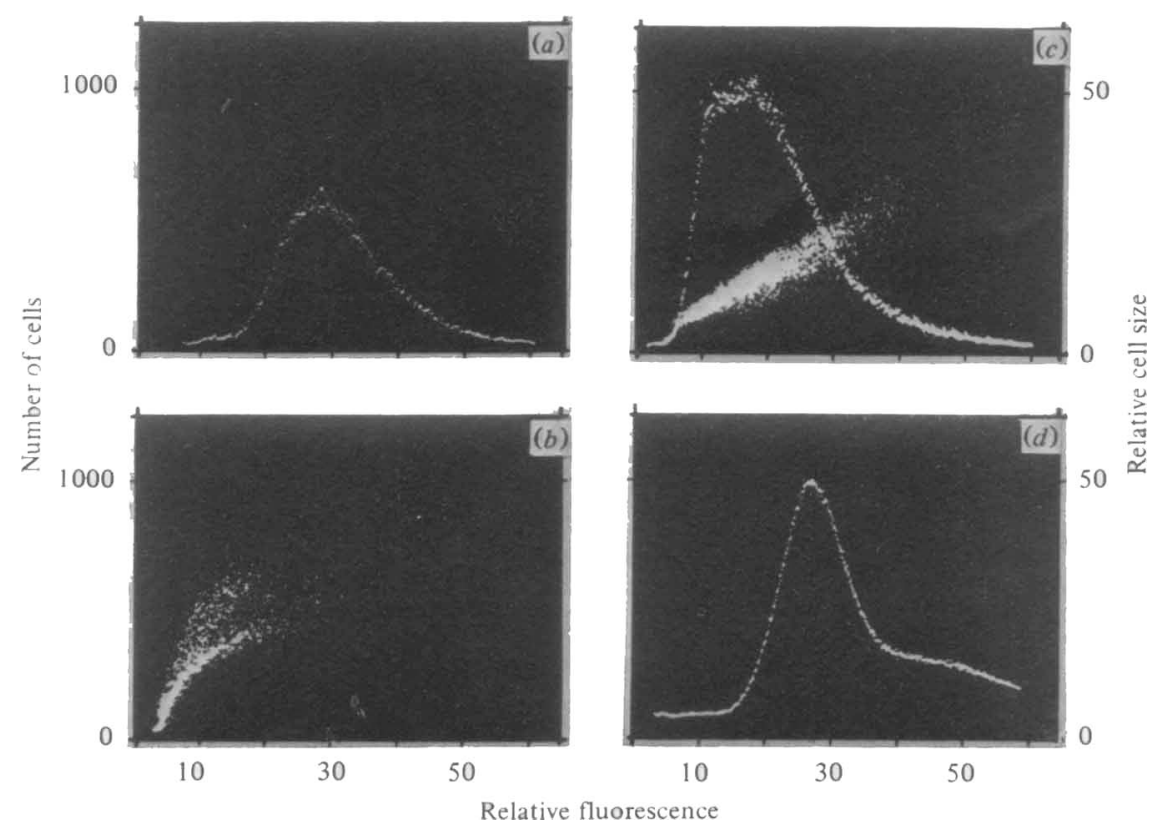

Fig. 2. Protein distributions of (a) Escherichia coli, (b) Chlorella kessleri 8k, (c) Saccharomyces pastorianus and $(d)$ baker's yeast.

membrane separation (Hutter et al., 1978b). The DNA distributions of the first two peaks in Fig. $1(a, b, e, i$ and $j)$ are consistent with the separation of the cell cycle into G1, S, G2 and $M$ phases (Howard \& Pelc, 1953). DNA replication occurs in the $S$ phase, mitosis in the $M$ phase, while the G1 and G2 phases are 'gap' periods. Discontinuous DNA synthesis was not observed with the bacterial, algal or mould cells. Due to the low signal to noise ratio, the fluorescence light signals for Lactobacillus brevis and Lactobacillus casei were too faint to permit interpretation.

Euglena gracilis gave the most significant results. The first peak was situated by channel 111 and had a coefficient of variation of $3.23 \%$ [determined, assuming a Gaussian distribution for the peak, from $(\mathrm{FWHM} / \mathrm{PCH}) \times 0.425$, where $\mathrm{FWHM}$ is the full peak width at half maximum (in channels) and $\mathrm{PCH}$ is the position of the peak (channel number)]. The second peak was situated by channel 222 and the third by channel 334 . This type of fluorescence distribution has not previously been used to measure microbial DNA.

The protein contents of the different organisms increase and protein is synthesized during the cell cycle (Hutter \& Eipel, 1978b). Protein content distributions in Escherichia coli, Chlorella kessleri 8k, Saccharomyces pastorianus and baker's yeast are shown in Fig. 2. The yeast cells used in these experiments were actively growing (see Methods). Biochemical studies have indicated that cellular components may be synthesized either discontinuously or continuously (Williamson \& Scopes, 1961; Williamson, 1965; Duffus, 1971; Halvorson et al., 1971; Mitchison, 1971; Hartwell, 1974; Smith \& Berry, 1974). The protein distributions in Saccharomyces yeasts (Fig. $2 c, d$ ) did not show the separate peaks of the corresponding DNA distributions; thus, while DNA synthesis is discontinuous in these yeasts, protein is synthesized continuously throughout the cell cycle.

A number of methods have been developed to determine the ploidy of yeast cells, using cytological, biochemical and genetic criteria (Emeis, 1962; Esser \& Kuenen, 1965; Laskowski et al., 1960; Laskowski, 1962; Hutter, 1975). Some of these methods were difficult and time-consuming. Using flow cytometry, we have developed a method of ploidy determination which is both rapid and precise. Since DNA plays an important role in the building 

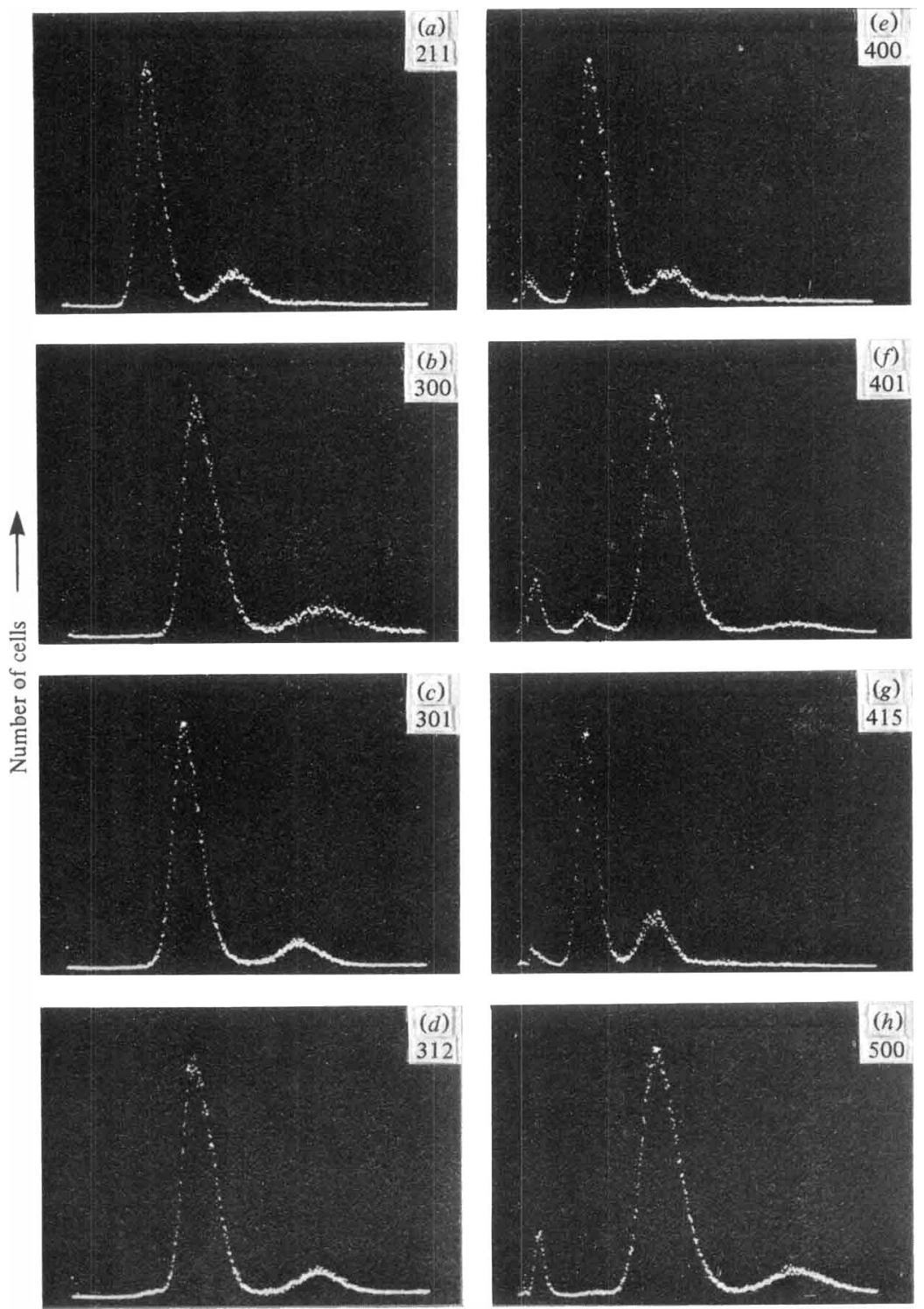

Relative fluorescence

Fig. 3. DNA distributions of Saccharomyces cerevisiae strains with different ploidy: diploid (211), triploid $(300,301,312)$, tetraploid $(400,401,415)$ and pentaploid $(500)$.

up of chromosomes, the DNA content of the nucleus must increase in proportion to ploidy. In previous biochemical methods, ploidy was determined by measuring the DNA content of the cell mass and then counting the number of individual cell nuclei. Using flow cytometry, the DNA content of individual cells is measured and used to determine ploidy.

The DNA distributions in exponentially growing populations of eight Saccharomyces cerevisiae strains with different ploidies were examined (Fig. 3). Clear shifts in the frequency distribution were observed for different strains, for example Fig. 3( $a, b)$. Consistent with its ploidy, the tetraplont 401 (Fig. $3 f$ ) had more DNA than the diplont and triplonts (Fig. $3 a$ to $d$ ). However, the supposed tetraplonts 400 and 415 (Fig. $3 e, g$ ), as well as the pentaplont 500 (Fig. $3 h$ ), had different ploidy levels. This could only be explained by a modification 
of the chromosomes in the course of establishment of the yeast genus, leading to aneuploidy or even polyploidy. The presumed tetraplonts 400 and 415 seemed to be more like diplonts, while the presumed pentaplont 500 was more like a tetraplont. While the DNA distributions of the diplont and triplonts consisted of only two peaks, the tetraplonts and the pentaplont showed additional small peaks in their DNA histograms which were not consistent with the results of Howard \& Pelc (1953). The first small peaks of these histograms are probably caused by damaged or degenerated cells with a weak fluorescence intensity. We conclude that flow cytometry can be used to determine the degree of ploidy of yeasts.

Our results show that flow cytometry can be of value in determining cellular components of different micro-organisms. Its main advantages are the speed at which measurements can be made, its sensitivity to more than $10^{-14}$ g DNA per cell (Kornberg, 1974; Laskowski et al., 1960) and the possibility of screening large populations.

We wish to thank Miss U. Punessen and Mr T. Görtz for their excellent technical assistance in preparing the samples.

\section{REFERENCES}

Bailey, J. E., Fazel-Madjlessi, J., McQuitty, D. N., Lee, L. Y., Allred, J. C. \& Oro, J. A. (1977). Characterization of bacterial growth by means of flow microfluorometry. Science 198, 1175-1176.

DitTRICH, W. \& GöHDE, W. (1969). Impulsfluorometrie bei Einzelzellen in Suspension. Zeitschrift

für Naturforschung 24b, 360-361.

Duffus, J. H. (1971). The cell cycle in yeast. Journal of the Institute of Brewing 77, 500-508.

EMEIS, C.-C. (1962). Aneuploide Hefen. Zentralblatt für Bakteriologie, Parasitenkunde, Infektionskrankheiten und Hygiene (Abteilung I, Medizinische Originale) 184, 247-250.

EsSER, K. \& KuENEN, R. (1965). Genetics of Fungi. Berlin: Springer Verlag.

Falchuk, K. H., Krishan, A. \& Vallee, B. L. (1975). DNA distribution in the cell cycle of Euglena gracilis. Cytofluorometry of zinc deficient cells. Biochemistry 14, 3439-3444.

GöHDE, W. (1972). Automation in der quantitativen Zytologie mit dem Impulscytophotometer. $G B K$ Mitteilungsdienst 6, 255-276.

Halvorson, H. O., Carter, B. L. A. \& Tauro, P. (1971). Synthesis of enzymes during the cell cycle. Advances in Microbial Physiology 6, 47-106.

Hartwell, L. H. (1974). Saccharomyces cerevisiae cell cycle. Bacteriological Reviews 38, 164-198.

Howard, A. \& Pelc, S. R. (1953). Synthesis of deoxyribonucleic acid in normal and irradiated cells and its relation to chromosome breakage. Heredity 6 (Suppl.), 261-273.

HutTER, K.-J. (1974). Untersuchungen über die DNS-, RNS- und Proteinsynthese von Hefezellen der Gattung Saccharomyces mit Hilfe neuer fuorometrischer Verfahren. Dissertation, T.U., Berlin, no. 19/13.

HutTER, K.-J. (1975). Ploidiegradbestimmung von Saccharomyces-Hefen. Chemie, Mikrobiologie, Technologie der Lebensmittel 4, 105-109.

HutTer, K.-J. \& EIPEL, H. E. (1978a). DNA distribution of yeast by flow cytometry. FEMS Microbiology Letters 3, 35-38.

HutTer, K.-J. \& Eipel, H. E. (1978b). Protein content distribution in population of baker's yeast. European Journal of Applied Microbiology and Biotechnology 5, 203-206.

Hutter, K.-J., GöRtz, H. T., Oldiges, H. \& EIPEL, H. E. (1978a). Durchflusszytophotometrische Bestimmung des DNS-Gehaltes von Nectria coccinea Pers. ex Fr. bei Fungizideinwirkung. Chemosphere 7, 51-58.

Hutter, K.-J., Görtz, H. T. \& EIPEL, H. E. $(1978 b)$. Different stages of DNA synthesis during the growth of Saccharomyces cerevisiae. FEMS Microbiology Letters 3, 291-294.

KAMENTSKY, L. A. (1970). Rapid Cell Spectrophotometer for Cell Identification and Sorting. Edited by D. M. D. Evans. London: E \& S Livingstone.

Kamentsky, L. A., Melamed, M. R. \& Derman, H. (1965). Spectrophotometer: new instrument for ultrarapid cell analysis. Science 150, 630-631.

Kessler, E. \& CzyGan, F. C. (1970). Physiologische und biochemische Beiträge zur Taxonomie der Gattung Chlorella. Archiv für Mikrobiologie 70, 211-216.

Kornberg, A. (ed) (1974). DNA Synthesis. San Francisco: W. H. Freeman.

Laskowski, W. (1962). Über den Aufbau weitestgehend isogener, homozygoter penta- und hexaploider Stämme sowie den Einfluss bestimmter mutierter Allele auf die Strahlenresistenz. Zeitschrift für Naturforschung 17b, 93-108.

Laskowski, W., Lochmann, E. R., Wacker, A. \& STEIN, W. (1960). Biochemische Eigenschaften in Abhängigkeit vom Ploidiegrad und Kombination der Paarungstypallele. Zeitschrift für Naturforschung 15b, 730-734.

Mitchison, J. M. (1971). Biology of the Cell Cycle. Cambridge: Cambridge University Press.

PaAu, A. S., Lee, D. \& Cowles, J. R. (1977a). Comparison of nucleic acid content in populations of free-living and symbiotic Rhizobium meliloti by flow microfluorometry. Journal of Bacteriology 129, 1156-1158.

PaAu, A. S., Cowles, J. R. \& Oro, J. (1977b). Flowmicrofluorometric analysis of Escherichia coli, Rhizobium meliloti, and Rhizobium japonicum at different stages of the growth cycle. Canadian Journal of Microbiology 23, 1165-1169. 
Skogen Hagenson, M. J. (1976). A high efficiency flow microfluorometer: application to bacterial fluorescence. MS thesis, Iowa State University, Ames, U.S.A.

Slater, M. L., Sharrow, S. O. \& Gart, J. J. (1977). Cell cycle of Saccharomyces cerevisiae in populations growing at different stages. Proceedings of the National Academy of Sciences of the United States of America 74, 3850-3854.

SMith, J. E. \& BerRy, D. R. (editors) (1974). An Introduction to the Biochemistry of Fungal Development. London \& New York: Academic Press.
Streble, E. \& Krauter, D. (editors) (1974). Das Leben im Wassertropfen. Stuttgart: Franckh'sche Verlagsbuchhandlung.

STRUGGER, S. (1949). Fluoreszenzmikroskopie und Mikrobiologie. Hanover: M. \& S. Schaper.

Williamson, D. H. (1965). The timing of deoxyribonucleic acid synthesis in the cell cycle of Saccharomyces cerevisiae. Journal of Cell Biology 25, 517-528.

Williamson, D. H. \& Scopes, A. W. (1961). Protein synthesis and nitrogen uptake in synchronously dividing culture of Saccharomyces cerevisiae. Journal of the Institute of Brewing 67, 39-42. 